\title{
FECAL SLUDGE MANAGEMENT OF DUHOK CITY AND 4 IDPS AND REFUGEES CAMPS
}

\author{
SHAWKAT AHMED KOCHARY ${ }^{1}$ \\ Dept. of Civil Engineering, College of Engineering, University of Duhok, Kurdistan Region-Iraq
}

(Accepted for Publication: December 8, 2020)

\begin{abstract}
This study aims to assess the condition of fecal sludge management (FSM) services of non-sewered (on-site) sanitation systems in Duhok city and Chamishko, Kaparto2, Sharia IDPs and Domiz1 refugees camps. Duhok city was selected as a case study while other locations were selected for their formally temporal status besides their difference in location, size, and level of existing proper service delivery. Shit flow diagrams (SFD) for on-site sanitation systems of interested areas were produced to identify the service outcomes and where improvements are needed to eliminate the negative impacts of FS on both public health and the environment. The study revealed that sanitation delivery services were at very good level in Kabartu2 camp as it has a wastewater treatment plant WWTP of $900 \mathrm{~m}^{3} /$ day capacity and in Sharia camp as it has a (Package Sewage) treatment plant of $1760 \mathrm{~m}^{3} /$ day capacity. In Domiz1 camp, the sanitation services were at poor level even though $25 \%$ of its generated wastewater transports to Kabartu2 WWTP for treatment. Similarly, the sanitation service level in both Duhok city and Chamishko camp were poor and very poor respectively where urgent improvements are needed. Recommendations were proposed to the decision makers of local authority to take proper actions.
\end{abstract}

KEYWORDS: Fecal Sludge management, Shit flow diagrams, (on-site) sanitation, Duhok city, IDPs and Refugees camp

\section{INTRODUCTION}

A s of today 2.7 billion people worldwide (in rural and urban areas) are served by onsite sanitation systems as predominant options from which, only 39 percent is estimated to be connected to sewers (Baum et al., 2013).

This number is expected to raise to 5 billion by 2030 (Strande and Brdjanovic, 2014). About 40 percent of world's population have been reported with lack of basic sanitation (Massoud et al., 2009).

It has been demonstrated that fecal sludge management (FSM) technologies in urban areas costs five times less expensive than the conventional sewer-based solutions (Dodane $e t$ al., 2012) for their construction, operation, maintenance, and repair. Sludge management from onsite facilities has therefore traditionally received little to no attention of most municipal engineers and the onsite technologies has viewed as only temporary solutions until sewers could be built. However, engineers and people started nowadays to consider the onsite technologies as more practical and more sustainable alternative on long-term basis than the expensive sewer-based systems.

Although the sanitation needs, in many urban of low to middle income countries, are met through onsite technologies at range much wider than sewer systems (Strande and Brdjanovic, 2014), there is a critical need of FS system, particularly at high densely populated cities, to be managed safely and where treatment to be placed through the sanitation service chain (SSC) as FSM will came into the spotlight and play a 
vital role in global sanitation in the future (Hawkins et al., 2017). To readily understand how excreta is managed in rural and urban areas and how it flows through the SSC, engineers and planners nowadays use a graphical representation names Shit Flow Diagram (SFD) as an effective tool for their sanitation rapid assessment. In 2013, water and sanitation program of the World Bank has carried out an analysis of excreta management and developed new tools for assessing the context and outcomes of excreta flow in 12 cities (Blackett et al., 2015). Martinez et al., (2017) have used SFD methodology in assessing the SSC in Kumasi city of Ghana for a period of 10 years in order to study and model the impact of three sanitation investment projects as SFD allows stakeholders to identify how future investment projects may change the flow of excreta in cities. For planning purposes, Peal et al., (2020) have implemented SFD diagrams methodology to represent, report and rapidly assess the sanitation of 39 cities around the world including: Africa, East Asia, Latin America, and South Asia. The objective of this study was to assess the condition of fecal sludge management (FSM) services for Duhok city center and four temporal IDPs and refugee camps, produce SFD diagrams to identify the sanitation service outcomes and where improvements are needed, and suggest different scenarios to improve the level of sanitation service delivery for area of interest in order to eliminate the negative impacts of fecal sludge on both public health and the environment.

\subsection{Poor Sanitation; Health and Environment}

On-site storages (latrine pits or septic tanks) are usually used to improve the surrounding environment by reducing people's exposure to pathogens. However, these pits and tanks will eventually expose people to insanitary conditions when get full of the accumulated sludge if not replaced or properly emptied. Poor sanitation and FSM have negative impacts not only on human health but also affect the environment through the contamination of water bodies, soils, food sources, and spreads of flies. It transmits diseases such as cholera, diarrhea, dysenteries, typhoid, hook worms, stunting and others (Ritchie and Roser, 2019). The most serious threat to human health and the environment is the groundwater contamination (Yates, 1985) while, the most frequently reported cause related to water-borne diseases is the high density of bad septic tank systems (Rubin, 2002; USEPA, 2002). Unsafe sanitation is a leading risk factor for death around the world and particularly at poorest areas. According to the Global Burden of Disease study 775,000 people died prematurely in 2017 as a result of poor sanitation (Jeemon et al., 2018).

\subsection{Composition of Human Excreta (Faeces and Urine)}

Nutrient excretion by human being is directly linked to the diet. Therefore, human is to excrete (defecate) the same amount of nutrients that he/she takes in the diet except for children who retain a small proportion for bones to grow Figure 1. The main nutrients for human body include: Organic matter, Nitrogen, Phosphorous, and Potassium. Up to $70 \%$ of Organic matter excretes in feces and $13 \%$ in dry urine solids. Moreover, urine contains the largest proportion of Nitrogen 90\% (Jönsson et al., 2005), Phosphorous as $\mathrm{P}_{2} \mathrm{O}_{5}(50-65 \%)$, and Potassium as $\mathrm{K}_{2} \mathrm{O}(50-80 \%)$ found in excreta released from the human body (Heinonen-Tanski and van Wijk-Sebesma, 2005). 


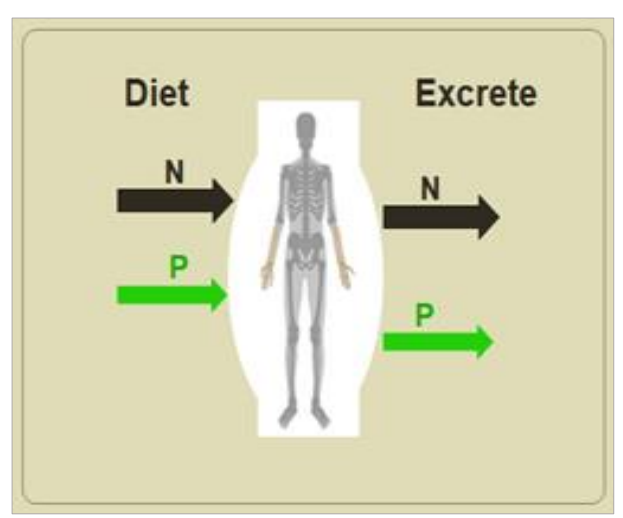

Fig. (1): Composition of Human Excreta

\subsection{Elements of Sanitation Service Chain (SSC)}

In many non-sewered areas in developing countries, FSM services are often unavailable or at least are unregulated, unhygienic and unsafe even when available. This can lead to water pollution and spreading of pathogens into the environment resulting in adverse impacts on both public health as well as the environment. The elements of SSC are described in the following:

SSC: Is a series of stages that shows the pathways of fecal sludge of on-site sanitation systems produces by contributing population Figure 2. It consists of the following: Capture, storage, removal and transport, treatment and, end use / or safe disposal.

FSM: Is a systems approach for implementation and operation that includes safely collection (emptying), transportation, treatment, and end use/or disposal of fecal sludge from on-site sanitation technologies like pit latrines, septic tanks, and other on-site sanitation facilities.

Open defecation: Is the practice of defecating in open areas such as open fields, open water bodies, open gutters, open spaces without any proper disposal of human excreta. Open defecation is classified as unimproved sanitation.

Reuse: Is the return of a good or product to the economy to be used in the same way as before, with no change in its shape or nature.

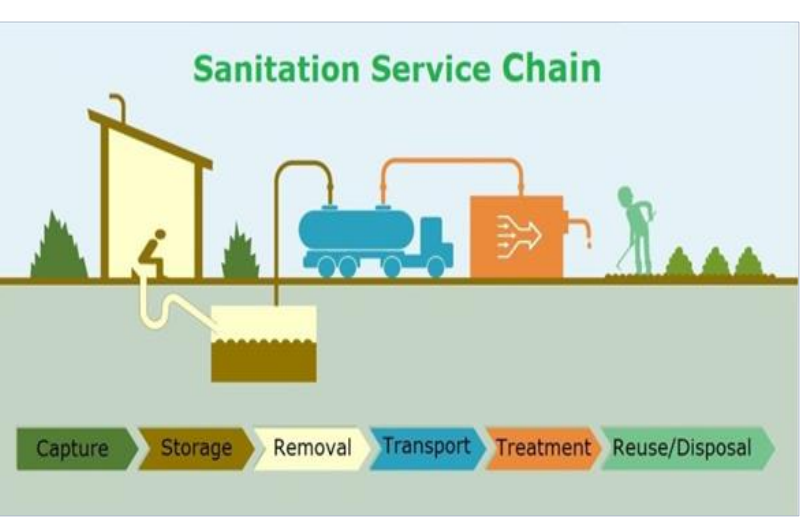

Fig. (2): After www.gatesfoundation.org (India office)

Final disposal: The final depositing of MSW at a site in appropriate conditions to prevent damage to the ecosystems.

Treatment: The process of physical, chemical or biological transformation of municipal solid waste (MSW) to obtain sanitary and/or economic benefits and to reduce or eradicate their harmful effects on man and on the environment.

\subsection{Shit flow diagram (SFD)}

SFD diagram is an effective tool for engineers, planners, and decision-makers to readily understand and communicate how excreta is or is not managed as it physically flows through the SSC from defecation to end-use/or disposal. It provides a strategic overview of the sanitation in a city or town as it presents a clear picture of the service delivery as well as the outcomes arising from wastewater and FSM practices. It also shows where improvements are needed by detecting the risks and weaknesses along the sanitation chain. It usually expresses in terms of the percentage of the population.

\subsection{Key Facts}

In 2017:

○ Almost 1.6 million people died from diarrheal diseases globally. Chronic diarrhea delays child development through hindering the absorption of necessary nutrients needed for his body, mind and immune system. 
- Only 39 percent of people worldwide is estimated to be connected to sewers (Jönsson $e t$ al., 2005).

○ 45 percent of world population (3.4 billion people) have delivered sanitation service management safely.

○ 40 percent of world population (3.0 billion people) absences basic sanitation services.

- 15 percent of world population (1.1 billion people) are still practicing outdoor defecation (Ritchie and Roser, 2019).

\section{METHODOLOGY}

\subsection{Site visits and data collection}

In order to collect data and closely identify the existing situation of area of interest, sites visit have been conducted to Chamishko, Kaparto2, Sharia IDPs camps and Domiz1 refugees camp in addition to related governmental directorates of Duhok city including: Directorate of sewerage, directorate of municipal, directorate of environment, and directorate of census Figure 3. Data were then crosschecked with data provided by the NGOs as secondary sources.

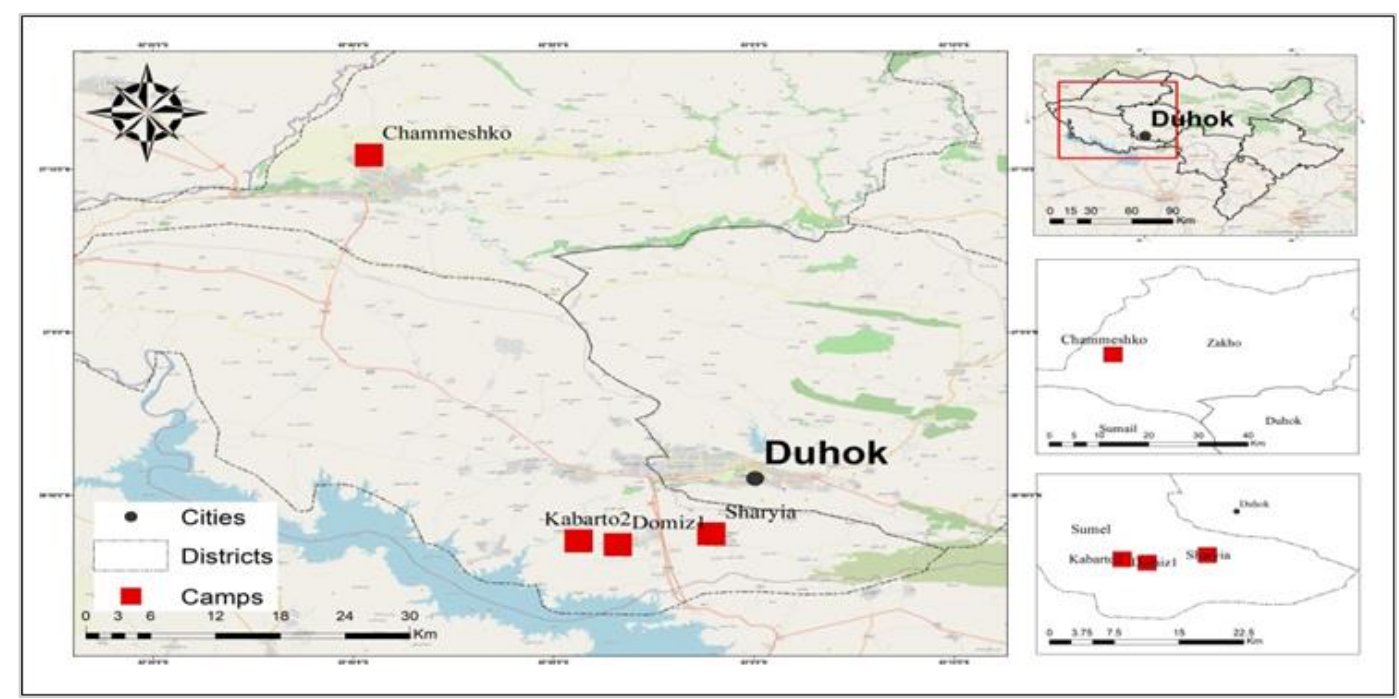

Fig. (3) Location of IDPs/Refugees camps and Duhok city center

\subsection{Existing on-site sanitation system of area of interest}

\subsubsection{Duhok city center}

As of today, Duhok city has no public sewer system nor wastewater treatment facility. The sewerage directorate has installed only $15 \%$ of city sewer network (Mizzouri et al., 2020) which, serves only some areas in collecting storm water and grey wastewater and discharges directly into Duhok and Hishkarow rivers until eventually ends up in Mosul Lake while black wastewater drains directly into individual septic tanks which, mostly seeps through the soil contaminating regional ground water for the absence of governmental regulations Figure 4. 

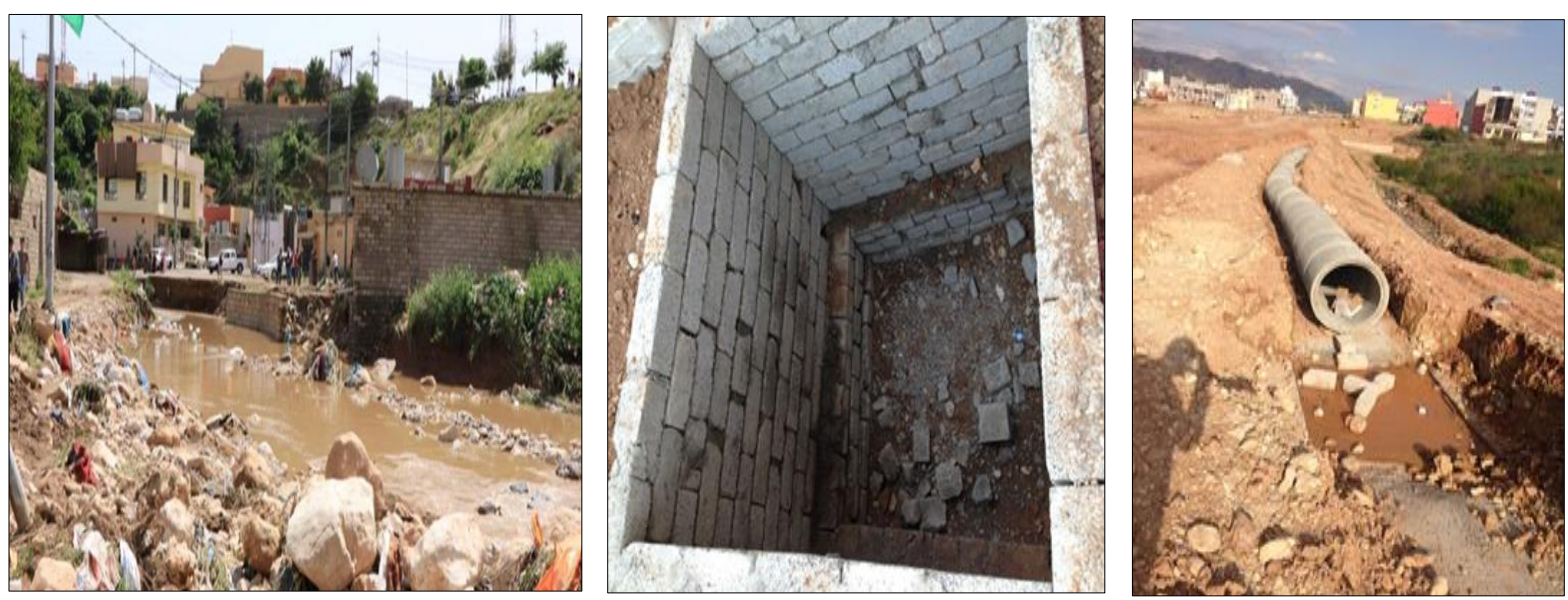

Fig. (4) Hishkarow river in Duhok city, a non-regulated Septic tank, and New sewer line under construction

Duhok city sewer system is about $60.3 \mathrm{~km}$ long and consist of old and non-connected sewer lines with almost 70 percent of inaccessible manholes of $60 \mathrm{~cm}$ openings with inefficient maintenance and bad management. The amount of wastewater that flashes directly into septic tanks is estimated to be more than $665,875 \mathrm{~m}^{3} /$ month (eq. to $8.0 \mathrm{MCM}$ ). According to USEPA, (1997), Duhok city is classified as a high septic tank density area as it comes with houses of average lots size of $200 \mathrm{~m}^{2}$ and each house has

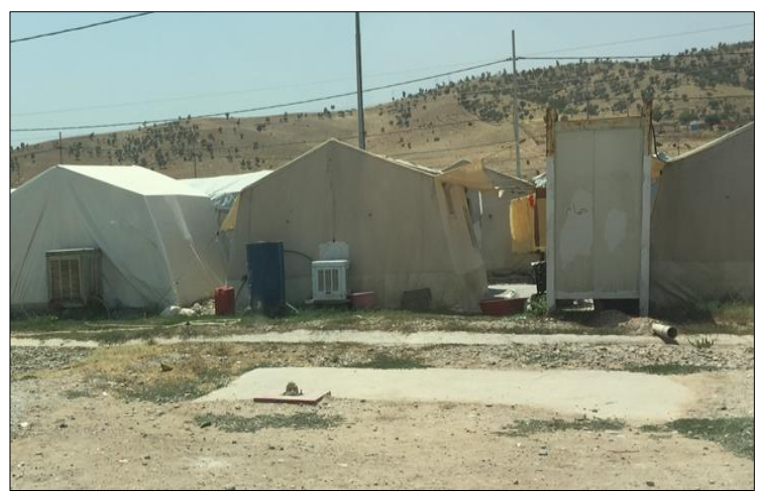

one of non-plastered walls and opened bottom septic tank.

\subsubsection{Chamishko IDPs camp}

Chamishko IDPs camp has no sewer systems nor wastewater treatment facility. All produced grey and black wastewater collects into 283 collective septic tank systems of permeable walls and sealed bottom (as one collective tank per 20 families) Figure 5. All collected wastewater is dumping into an open area locates $4.5 \mathrm{~km}$ away from the camp.

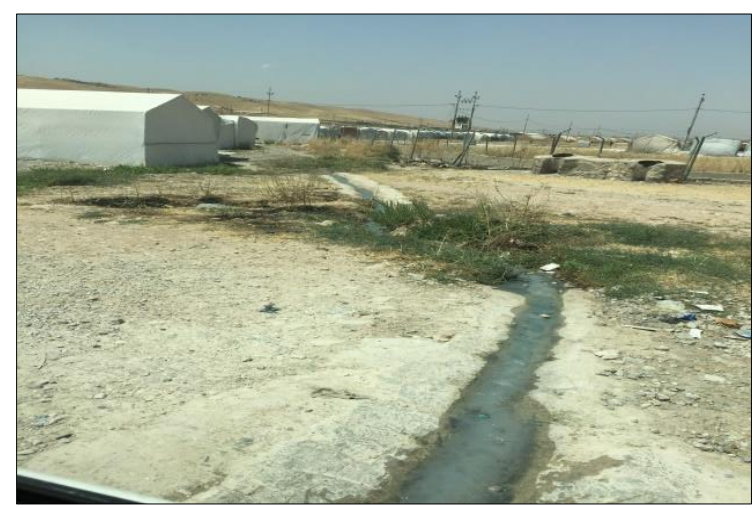

Fig. (5): Collective septic tank systems and outer sewer line

\subsubsection{Kaparto2 IDPs camp}

Kaparto2 IDPs camp has no sewer system. But, it has a WWTP of $900 \mathrm{~m}^{3} /$ day max capacity Figure 6. All grey and black wastewater produced from camp residents collects into sealed collective septic tank systems of 45 cubic meter designated for 20 families. While grey wastewater flows via open channels, collected black wastewater transports to the WWTP via vacuum trucks for treatment. The WWTP is currently operates at $450 \mathrm{~m}^{3} /$ day capacity and the wastewater discharged at the effluent uses only for crops irrigation at neighboring areas. Final disposal of fecal sludge is transferred to Quashe village for incineration. 

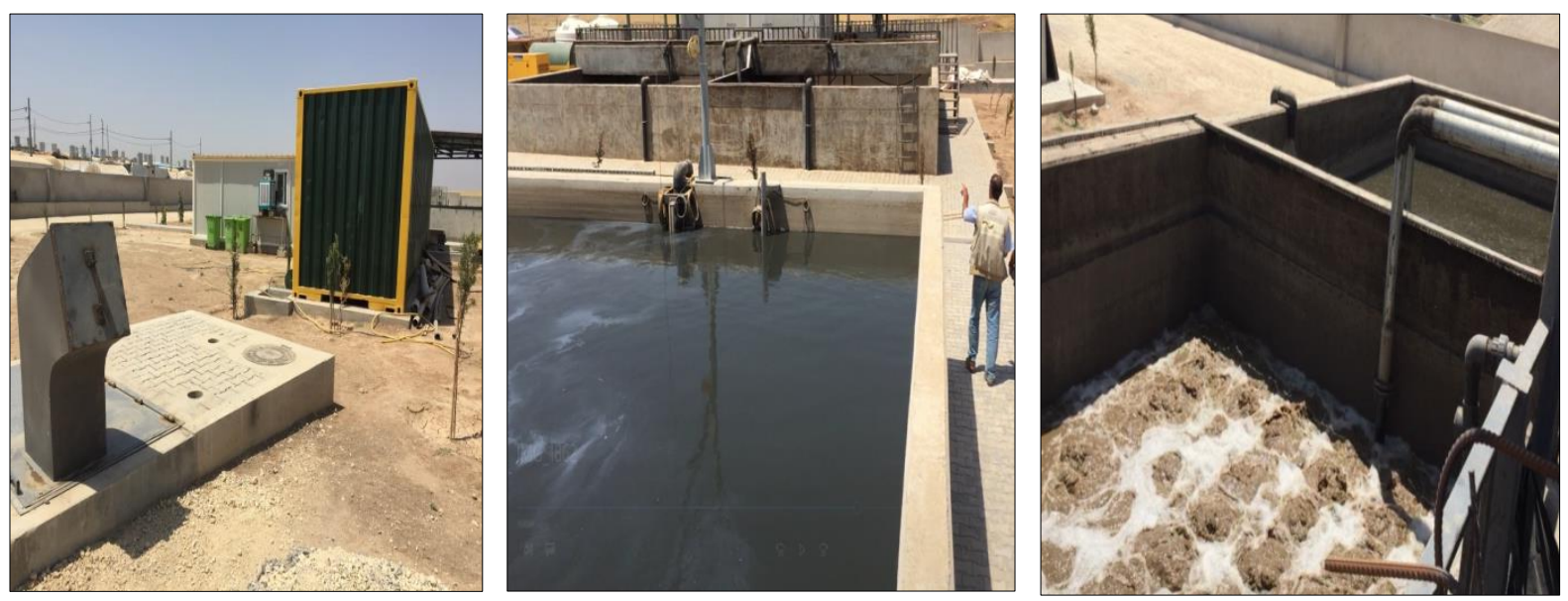

Fig. (6): Wastewater treatment plant of Kaparto2 IDPs camp

\subsubsection{Sharia IDPs camp}

Sharia IDPs camp has no sewer system. However, it has a package sewage of 10 units as a portable WWTP with $1760 \mathrm{~m}^{3} /$ day capacity Figure 7. All produced grey and black wastewater from camp residents collects into sealed collective septic tanks and transports through vacuum trucks to the WWTP for treatment. The wastewater discharged at the effluent uses for crops irrigation only.
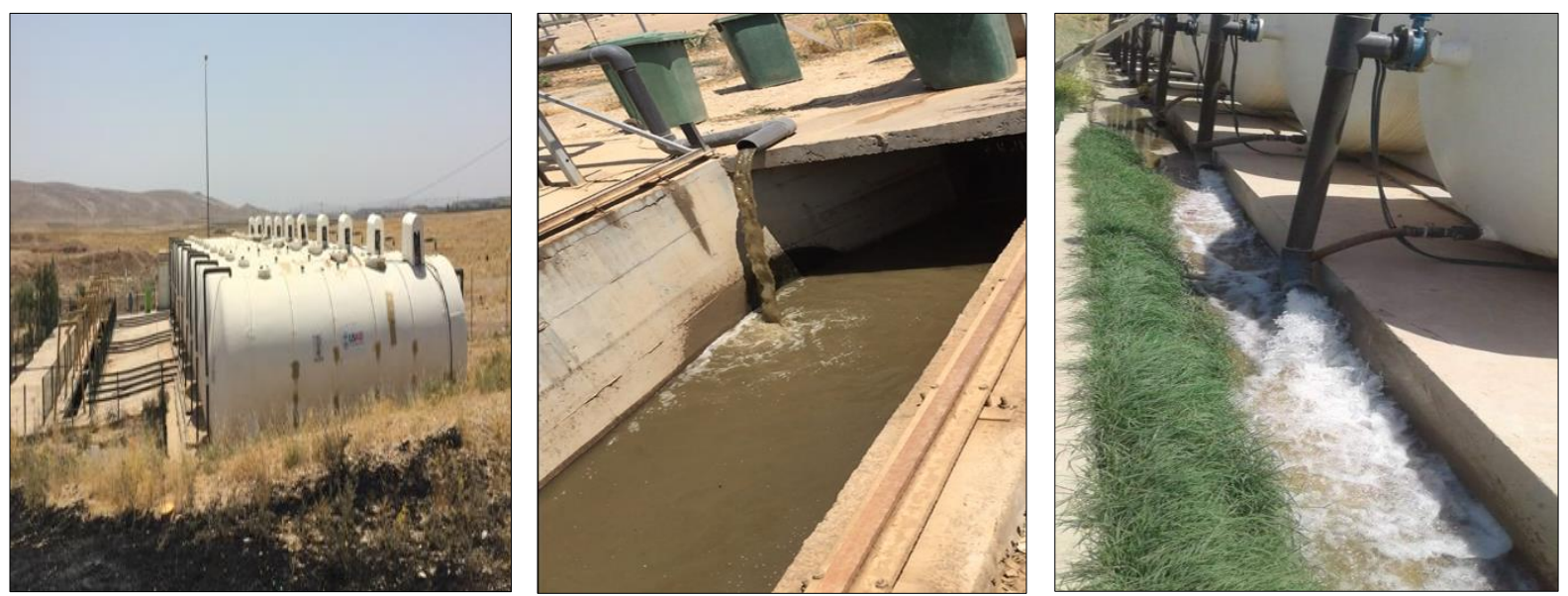

Fig. (7): Package sewage treatment plant of Sharia IDPs camp

\subsubsection{Domiz1 refugees camp}

Domiz1 refugees camp has no sewer system nor wastewater treatment facility Figure 8 . It produces grey wastewater with neutral $\mathrm{pH}$ and high values of total dissolved solids (TDS), chemical oxygen demand (COD), magnesium and nitrate that exceeds the permissible level of Iraqi standards (Mizzouri et al., 2017). All grey and black wastewater produced from camp residents collects into sealed collective septic tank systems of 40 cubic meter designated for 40 families each. Only $25 \%$ of collected wastewater transports through vacuum trucks to WWTP of Kaparto2 camp for treatment while, the rest of collected wastewater dumps without any treatment in a topographically easy flow open area. 

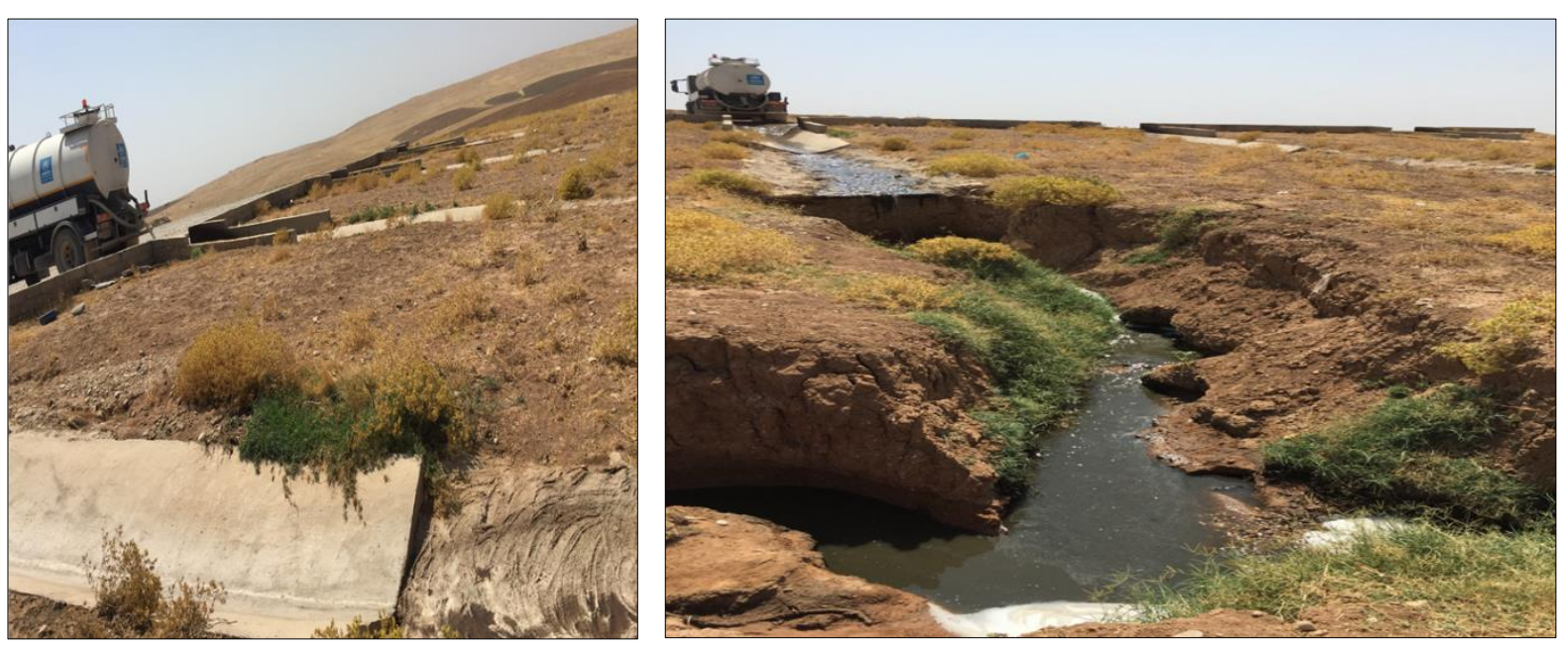

Fig. (8): Dumping the wastewater of Domiz1 refugees camp at open area

\subsection{Quantities of Grey and Black Wastewater}

All quantities of water consumption and black wastewater generation were actual and been taken directly from related parties of IDPs and refugees camps and governmental bodies. Water consumption in all camps was between 70 and 80 L/c.d while in Duhok city was 233 L/c.d. The average production of grey wastewater for all locations was expected to be $52 \%$ of the total supplied waster depending on the consideration that $80 \%$ of water consumption is wastewater (Finley et al., 2009) from which, 65\% is grey wastewater as grey wastewater represents $50-80 \%$ of the total wastewater (Siggins et al., 2016). All collected (actual) and expected data are illustrated in Table1.

Table (1): Sanitation data of areas of interest

\begin{tabular}{|c|c|c|c|c|c|}
\hline Location & Population & $\begin{array}{c}\text { Actual Water } \\
\text { Consumption } \\
\text { L/c.d }\end{array}$ & $\begin{array}{c}\text { Water } \\
\text { Consumption } \\
\mathrm{m}^{3} / \text { day }\end{array}$ & $\begin{array}{c}\text { Expected Average } \\
\text { Grey Wastewater } \\
\mathrm{m}^{3} / \text { day }\end{array}$ & $\begin{array}{c}\text { Quantity ** } \\
\text { Of Black Wastewater } \\
\mathrm{m}^{3} / \text { month }\end{array}$ \\
\hline Duhok City Center & 380,500 * & 233 & 88610 & 46,077 & $\begin{array}{c}6933 \\
(95 \% \mathrm{FS})\end{array}$ \\
\hline $\begin{array}{c}\text { Chamishko IDPs } \\
\text { Camp }\end{array}$ & 27,441 & 70 & 1921 & 999 & 7800 \\
\hline $\begin{array}{c}\text { Kaberto } 2 \\
\text { IDPs Camp }\end{array}$ & 13,565 & 70 & 950 & 494 & 2800 \\
\hline $\begin{array}{c}\text { Sharya } \\
\text { IDPs Camp }\end{array}$ & 16,420 & 80 & 1314 & 683 & 900 \\
\hline $\begin{array}{c}\text { Domiz } 1 \text { Refugees } \\
\text { Camp }\end{array}$ & 26385 & 78 & 2058 & 1070 & 8000 \\
\hline
\end{tabular}

* Duhok Directorate of Census, 2018. ** Collected directly from related parties

\subsection{Generation of SFD diagrams}

SFD diagrams for on-site sanitation systems of interested area were produced using SFD promotion initiative (https://sfd.susana.org/) of Sustainable Sanitation Alliance (SuSanA).
Reasonable assumptions were considered for data analysis and SFD diagrams generation. Duhok city center was selected as a big city with no WWTP facility, Chamishko as a biggest IDPs camp in Zakho city with no WWTP, Kabartu2 as 
an IDPs camp with WWTP facility of 900 $\mathrm{m}^{3} /$ day capacity, Sharia as an IDPs camp with (Package Sewage) treatment plant of 1760 $\mathrm{m}^{3} /$ day capacity, and Domiz1 as a biggest refugees camp in the area.

\section{RESULTS}

\subsection{SFD Diagram of Duhok city center}

SFD of Duhok city center Figure 9, describes how excreta is managed within Duhok city as it flows from user interface to the final disposal and it has the following stages:

\section{Containment}

Duhok city of 58448 households and 380500 individuals has no underground sewerage system. 100 percent of Duhok city households depends on on-site sanitation system. The on-site containments observed during the field visit were as follow:

$\circ$ Lined tanks with impermeable walls and open bottom connected to open ground (25\% population). This percentage was adopted only for the new expanded areas and the new construction system of complexes (apartment buildings) in the city only.

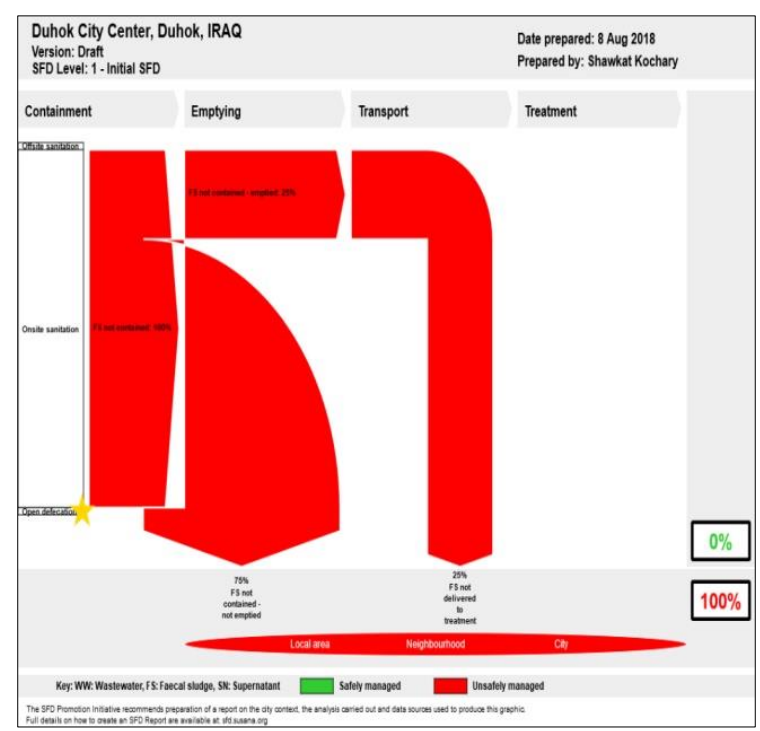

Fig. (9): Shit Flow Diagram of Duhok city center
○ Unlined pit with permeable walls and open bottom with no outlet (or overflow) where there is a significant risk of groundwater pollution $(75 \%$ population). This percentage was adopted for the old sanitation system of the city.

$\circ 0 \%$ of the population practice open defecation.

\section{Emptying, Transportation, and Treatment}

Emptying the containment systems in Duhok city takes place using governmental and private vacuum trucks

of $8 \mathrm{~m}^{3}$ capacity at a rate of 40 trips/ day and over five days a week.

$\circ$ It has been observed that $75 \%$ of on-site sanitation system used in the city have not been emptied from sewage ever since 15 years ago as their liquid sewage percolates through the soil while $25 \%$ of it is to be emptied as needed and transports for dumping at designated open area in Dilibe which, locates about 7 kilometers from Duhok city center without any treatment.

o Excreta of $100 \%$ population of Duhok city is unsafely managed for the absence of WWTP facility.

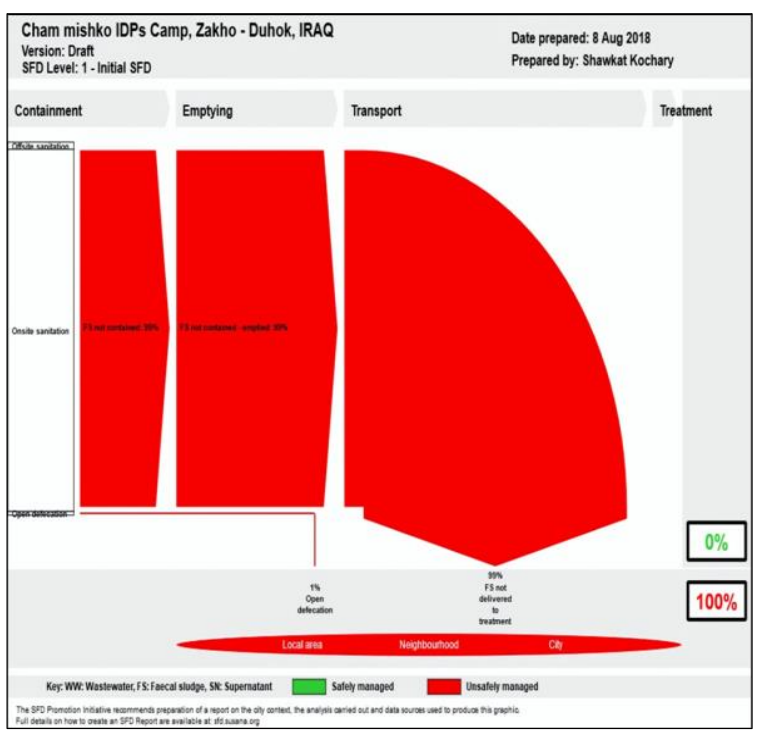

Fig. (10): Shit Flow Diagram of Chamishko IDPs camp 


\subsection{SFD Diagram for Chamishko IDPs camp}

SFD diagram of Chamishko as a biggest IDPs camp in Zakho city Figure 10 describes the FSM from production until the final disposal with the following stages:

\section{Containment}

Chamishko IDPs camp of 27,441 individuals has no underground sewerage system. 100 percent of households depends on on-site sanitation system. The on-site containments observed during the field visit were as follow:

$\circ$ Lined tanks with impermeable walls and open bottom, connected to open ground (99\% population).

o Open defecation practice expected to be $(1 \%$ population).

\section{Emptying, Transportation, and Treatment}

Emptying the containment systems in this IDPs camp takes place using governmental and private sector vacuum trucks at of 5 trucks of 7.5 $\mathrm{m}^{3}$ capacity. Each truck takes 8 trips per day and works 6 days a week.

$\circ 100 \%$ generated wastewater transports and disposes at an open area $5 \mathrm{~km}$ away from the IDP camp and without any treatment.

$\circ$ Excreta of $100 \%$ population of the camp is unsafely managed.

\subsection{SFD Diagram for Kabartu2 IDPs camp}

SFD diagram of Kabartu2 IDPs camp Figure 11

$\bigcirc$

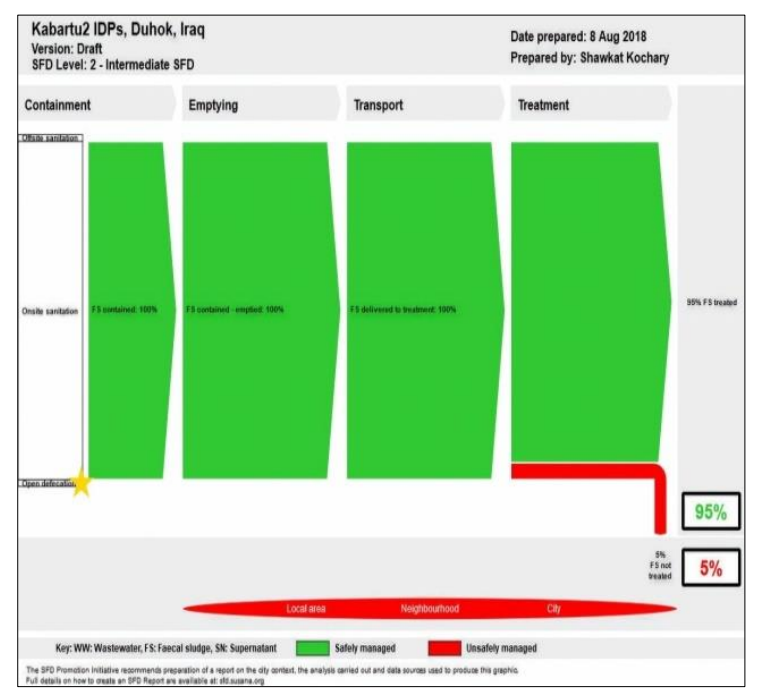

Fig. (11):. Shit Flow Diagram for Kabartu2 IDPs camp describes how fecal sludge is managed from production until the final disposal with the following stages:

\section{Containment}

Kabartu2 IDPs camp of 13565 individuals has no underground sewerage system. 100 percent of households depends on on-site sanitation system. The on-site containments in this IDPs camp were:

$\circ$ Fully lined (sealed) collective septic tanks (100\% population).

$\circ$ Open defecation practice ( $0 \%$ population).

\section{Emptying, Transportation, and Treatment}

o Emptying the containment systems in this IDPs camp takes place using a vacuum truck of $7.5 \mathrm{~m}^{3}$ capacity at rate of 14 trips per a day and 6 days a week.

$\circ 100 \%$ of generated wastewater transports to the WWTP established in the camp for $95 \%$ treatment. The discharged water at the effluent is not fully treated and not suitable for drinking purposes as it missing chlorination. However, it is used for crops irrigation. Fecal sludge collected from the plant transports for disposal at an open area.

$\circ$ Excreta of only $95 \%$ population of the camp is safely managed. Fecal sludge of $5 \%$ population remains untreated (unsafely managed).

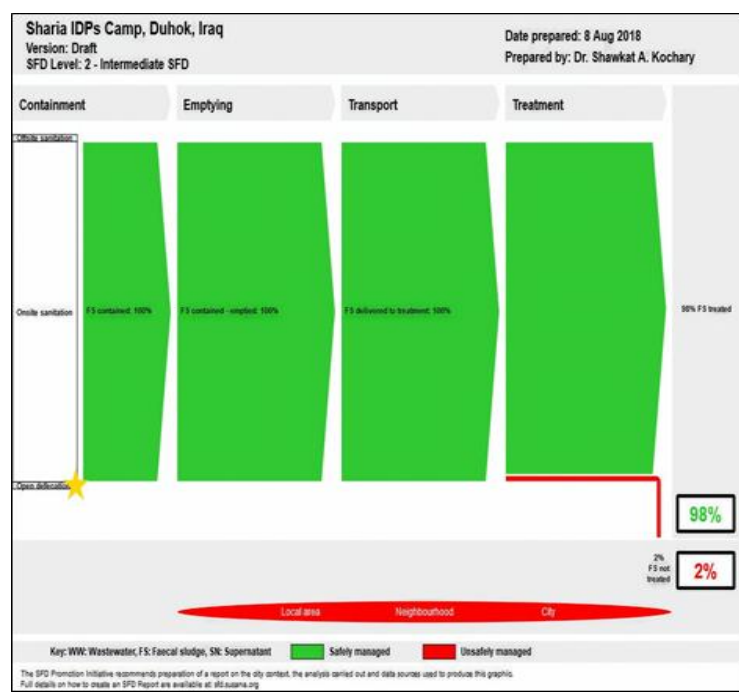

Fig. (12):. Shit Flow Diagram for Sharia IDPs camp 


\subsection{SFD Diagram for Sharia IDPs camp}

SFD diagram of Sharia IDPs camp Figure 12 describes the movement of fecal sludge from production to final disposal with the following stages:

\section{Containment}

Sharia IDPs camp of 16420 individuals has no underground sewerage system. 100 percent of households depends on the on-site sanitation system. The on-site containments in this IDPs camp were:

$\circ$ Fully lined (sealed) collective septic tanks (100\% population).

○ Open defecation practice ( $0 \%$ population).

\section{Emptying, Transportation, and Treatment}

o Emptying the containment systems in this IDPs camp takes place using vacuum trucks at rate of $1760 \mathrm{~m}^{3} /$ day.

- $100 \%$ of generated wastewater transports to the package sewage WWTP installed in the camp for $98 \%$ treatment. Discharged water at the effluent uses for irrigation purposes only.

○ Excreta of $98 \%$ population of Sharia IDPs camp is safely managed. Fecal sludge of $2 \%$ population remains untreated (unsafely managed).

\subsection{SFD Diagram for Domiz1 Refugees camp}

SFD diagram of Domiz1 Refugees camp Figure 13 describes the fecal sludge movement from production to disposal as in the following stages:

\section{Containment}

Domiz1 Refugees camp of 26385 individuals has no underground sewerage system. 100 percent of households depends on on-site sanitation system. Types of on-site containments observed during the field visit were:

o Fully lined (sealed) tanks.

- $25 \%$ of generated wastewater (including fecal sludge) transports to Kabartu2 WWTP for treatment ( $25 \%$ population).

$\circ 75 \%$ of generated wastewater (including fecal sludge) dumps (or connected) to open ground (75\% population).

$\circ 0 \%$ of the population practice open defecation (0\% population).

\section{Emptying, Transportation, and Treatment}

$\circ$ Emptying $100 \%$ of containment systems performs via 6 private vacuum trucks of (7.5 - 8) cubic meter capacity at rate of 8 trips per day and 5 days a week.

$\circ 25 \%$ of emptied wastewater is transported to Kabartu2 WWTP for $90 \%$ treatment (for irrigation purposes only) while $75 \%$ of it is transported to be dumped in an open ground. ○ Fecal sludge of $22 \%$ population of the camp is safely managed through Kabartu2 WWTP while the fecal sludge of $78 \%$ population is still managed unsafely

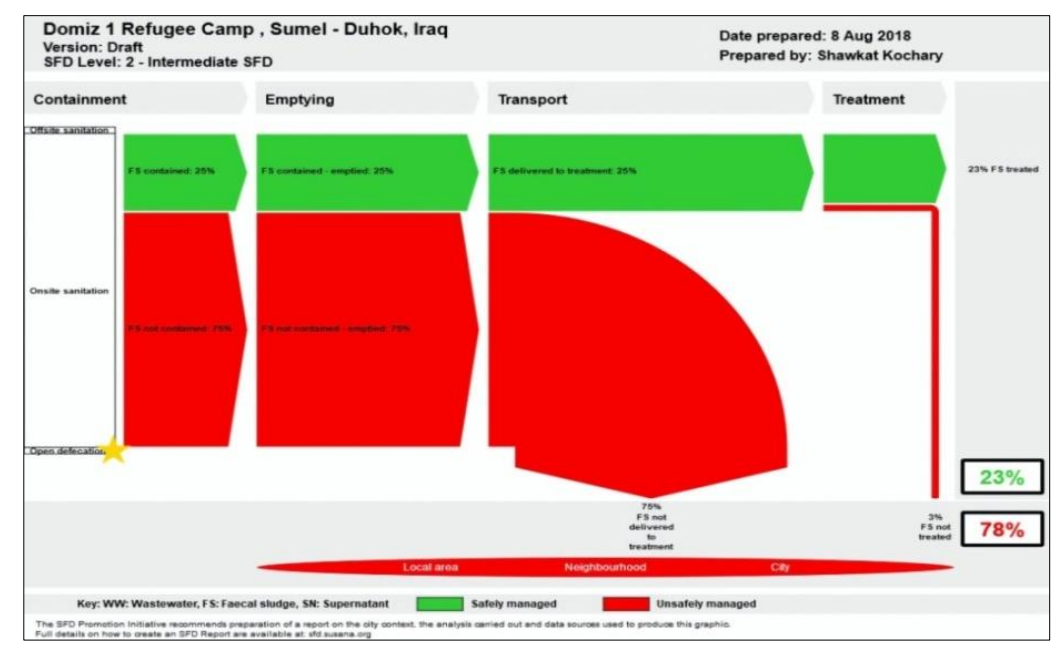

Fig. (13): Shit Flow Diagram for Domiz1 Refugees camp 


\section{DISCUSSION}

Sanitation service level in Duhok city and Chamishko IDPs camp were at poor level and the fecal sludge management in both location is absolutely not safe. This confidently attributes to 1. The absence of wastewater treatment facilities in both areas. 2. The absence of governmental regulations concerning the construction of onsite sanitation systems in Duhok city. 3. Bad management of municipals directorate that sponsors empting services and transporting of the generated wastewater at rates which, believes to be absolutely inappropriate with regards to corresponding population in addition to dumping the fecal sludge at open areas without any treatment.

Sanitation delivery services were at very good level in both Kabartu2 and Sharia IDPs camps with $95 \%$ and $98 \%$ safely fecal sludge management respectively. This attributes to the presence of wastewater treatment plant WWTP at Kabartu2 camp and the Package Sewage treatment plant at Sharia camp. The wastewater at the effluent in both facilities is clean enough to be used for irrigation only as their stage of chlorination is not enough to qualify as a disinfection process to be used for drinking purposes. Hence, disinfection process is needed to be improved.

SFD diagram of Domiz1 camp shows that the sanitation services were at poor level. It comes with $23 \%$ unsafe fecal sludge management where urgent improvements are needed. This attributes to the fact that only $25 \%$ of wastewater generated by camp population transports to Kabartu2 WWTP for treatment while the rest $75 \%$ is emptied and transported to be dumped at an open area within $5 \mathrm{~km}$.

\section{CONCLUSION}

1. The generated SFD diagrams shows that the sanitation service in Duhok city and Chamishko
IDPs camp were at poor and very poor level respectively as they both have a $100 \%$ unsafe fecal sludge management and urgent improvements are needed.

2. SFD diagrams shows that sanitation delivery services were at very good level in both Kabartu2 and Sharia IDPs camps with $95 \%$ and 98\% safely fecal sludge management respectively.

3. SFD diagram of Domiz1 camp shows that the sanitation service was at poor level and because of its unsafe fecal sludge management, urgent improvement in sanitation service is needed.

\section{Recommendations}

As per Duhok city, it recommends the following: 1. Either to construct a WWTP or to install package sewage system for wastewater treatment.

2. A code of regulations is to be issued in order to regulate the construction of new septic systems as well as the management of existing ones as the non-regulated onsite systems of Duhok city have proven inadequate and caused big implications on regional groundwater quality.

3. Local government is to improve the existing city sewer lines to decrease the losses in discharged wastewater that seeps downward towards groundwater.

4. Enforce the homeowners to de-sludge their onsite systems at less than 3 years interval specifically at shallow groundwater level areas and in all cases no longer than 7 years elsewhere.

5. A suitable fecal sludge dumping area to be appointed by the local government to be used as a dry bed or to burn the dried sludge.

As per Kabartu2 and Sharia IDPs camps, it recommends the following:

1. Enhancement of chlorination stage of treated wastewater to qualify as a disinfection process hereafter the water can be used to supply the camps residents for drinking purposes.

2. Fecal sludge resulted from their plants to be 
managed safely to produce organic fertilizers.

As per Domiz1 refugee camp: For sanitation services safely management, it recommends that leach field pipes to be installed and connected with the existing septic tanks in order to eliminate the quantity of generated wastewater. Hence, the quantity of generated wastewater can be significantly eliminated to less than $20 \%$ which, can be easily transported to and accommodated by Kabartu2 WWTP for treatment.

As per Chamishko IDPs camp: It recommends the following:

1. Installation of leach field pipes to be connected with the existing collective onsite systems to eliminate wastewater generation.

2. Installation of a package sewage system of 10 units for wastewater treatment.

3. Enhancement of sanitation service delivery by encouraging the camp residence to avoid open defecation via promotional programs.

\section{ACKNOWLEDGMENT}

This study was conducted within a jointly supported program of GIZ Organization (Deutsche Gesellschaft fur Internationale Zusammenarbeit) and University of DuhokKurdistan Region-Iraq.

\section{REFERENCES}

Baum, R., Luh, J., \& Bartram, J. (2013). Sanitation: a global estimate of sewerage connections without treatment and the resulting impact on MDG progress. Environmental science \& technology, 47(4), 1994-2000.

Blackett, I., Evans, B. E., Furlong, C., Hawkins, P., Kanathigoda, A. K., Luthra, B., ... \& Schoebitz, L. (2015). City level excreta flow analysis-the SFD Promotion Initiative.

Dodane, P. H., Mbéguéré, M., Sow, O., \& Strande, L. (2012). Capital and operating costs of full-scale fecal sludge management and wastewater treatment systems in Dakar, Senegal. Environmental science \& technology, 46(7), 3705-3711.

Finley, S., Barrington, S., \& Lyew, D. (2009). Reuse of domestic greywater for the irrigation of food crops. Water, air, and soil pollution, 199(1-4), 235-245.

Hawkins, P., Blackett, I., \& Heymans, C. (2017).
Poor-inclusive urban sanitation: An overview.

Heinonen-Tanski, H., \& van Wijk-Sijbesma, C. (2005). Human excreta for plant production. Bioresource technology, 96(4), 403-411.

Jeemon, P., Mini, G. K., Thankappan, K. R., \& Sylaja, P. (2018). GBD 2017 Population and Fertility Collaborators. Population and fertility by age and sex for 195 countries and territories, 1950-2017: a systematic analysis for the Global Burden of Disease Study 2017.

Jönsson, H., Baky, A., Jeppsson, U., Hellström, D., \& Kärrman, E. (2005). Composition of urine, feaces, greywater and biowaste for utilisation in the URWARE model. Urban water report, 2005(6).

Martinez, L. F., Furlong, C., \& Scott, R. E. (2017). Predicting the impact of sanitation investment projects on the Sanitation Service Chain (SSC), using excreta flow diagrams (SFDs).

Massoud, M. A., Tarhini, A., \& Nasr, J. A. (2009). Decentralized approaches to wastewater treatment and management: applicability in developing countries. Journal of environmental management, 90(1), 652-659.

Mizzouri, N. S., Kochary, S. A., \& Barwari, N. (2020, February). Decentralized/Semi-Centralized Sanitation Solutions in Duhok Governorate-Case Study. In 2020 6th International Engineering Conference "Sustainable Technology and Development"(IEC) (pp. 1-6). IEEE.

Peal, A., Evans, B., Ahilan, S., Ban, R., Blackett, I., Hawkins, P., ... \& Veses Roda, O. (2020). Estimating safely managed sanitation in urban areas; lessons learned from a global implementation of excreta-flow diagrams.

Ritchie, H., \& Roser, M. (2019). Sanitation. Our World in data.

Rubin, A. R. (2002). Fulfilling potential of on-site wastewater treatment. Biocycle, 43(1), 66-70.

Siggins, A., Burton, V., Ross, C., Lowe, H., \& Horswell, J. (2016). Effects of long-term greywater disposal on soil: A case study. Science of the Total Environment, 557, 627-635.

Strande, L., \& Brdjanovic, D. (Eds.). (2014). Faecal sludge management: Systems approach for implementation and operation. IWA publishing.

Sustainable Sanitation Alliance (SuSanA) https://sfd.susana.org/ accessed on Aug 08, 2018.

US Environmental Protection Agency. (2002). Onsite wastewater treatment systems manual. EPA625/R-00-008.

Yates, M. V. (1985). Septic tank density and groundwater contamination. Groundwater, 23(5), 586-591. 